\title{
WORKING OUT A RATIONAL MODEL OF LITHUANIAN CONSTRUCTION INDUSTRY DEVELOPMENT
}

\author{
Edmundas Kazimieras Zavadskas*, Artūras Kaklauskas** \\ * Department of Construction Technology and Management, First Vice-rector of Vilnius Gediminas Technical Univer- \\ sity, Saulètekio al. 11, LT-10223 Vilnius-40, Lithuania, \\ E-mail:Edmundas.Zavadskas@adm.vtu.lt
}

** Department of Construction Economics and Property Management, Vilnius Gediminas Technical University, Sauletekio al. 11, LT-10223 Vilnius-40, Lithuania,E-mail: Arturas.Kaklauskas@st.vtu.lt

Received 1603 2005; accepted 07042005.

\begin{abstract}
The research aim was to develop a model for determining rational micro and macro-level factors for the construction industry in Lithuania by undertaking a complex analysis of environment affecting it and to give recommendations on the increase of its competitive ability. In modelling and forecasting future perspectives and the main development trends of the Lithuanian construction industry, it is possible to be prepared for effective changes in environment. The analysis of construction industry in developed countries and Lithuania can allow identify areas where the situation in Lithuania is comparable, partly comparable with or quite different from the level attained by the above foreign countries. The data of this analysis can be used in identifying construction industry development trends in developed countries as well as providing some recommendations for Lithuania. Proposed model would be designed to give insights into the factors which affect the construction and which require effective management. In order to demonstrate the application of the above research to developing rational model of Lithuanian construction industry some recommendations for improving situation in Lithuanian construction are presented.
\end{abstract}

Keywords: construction industry, development, rational model, Lithuania.

\section{Introduction}

From 1990 to 2003, Lithuania's economy underwent some earthshaking changes in all of its sectors. Four distinct phases emerged during this period of economic development:

- From 1990 to1994, Lithuania experienced a dramatic economic decline. While changes in the structure and profile of the Lithuanian industry were underway, output began to stagger, falling slightly during the beginning of this period: 2.8 $\%$ in 1990 and $4.8 \%$ in 1991. However, during 1992, 1993 and 1994, industrial output plummeted $(28.6 \%, 34.4 \%$ and $38.1 \%$, respectively). By 1995 , industrial output was only $30.6 \%$ of that obtained in 1990. The plunging rate of Lithuania's industrial output can be compared to the drop in the gross domestic product (GDP).

- From 1995 to 1998, Lithuania entered a recovery period. The GDP reflected these growth trends. Reported growth rates were $3.3 \%$ in 1995, 4.7 \%in 1996 and $7.3 \%$ in 1997. However, the 1998 GDP fell slightly to 5.1 percent (see Table 1).

- At the end of 1998, the economic growth rate slowed down due to the financial crisis in Russia. The Russian economic crisis influenced the entire Lithuanian economy, resulting in a downturn in
GDP growth to $4.1 \%$ in 1999 .

- From 2000 to 2003, Lithuania repeatedly entered a recovery period. The GDP reflected these growth trends. Reported growth rates were $4.0 \%$ in $2000,6.5 \%$ in 2001 and $6.7 \%$ in 2002 .

According to the data collected by the Lithuanian Statistics Department during the 1991-1998 period, construction volumes plunged approximately two-fold, and the construction materials industry's gross production by more than five-fold. The fall-off in the construction materials industry's gross production was much greater than that in construction volumes; the restructuring policy applied to construction (employment of new materials and construction methods) had moved significantly ahead, increasing the use of imported materials.

From 2001 to 2003, Lithuania's construction volume rose $(7.5 \%$ in 2001 and $13.1 \%$ in 2002.). Over the first quarter of 2003, Lithuanian construction volume rose of $19.5 \%$ if compared to the respective period last year. The Department of Statistics says that the growth was predetermined by rapid expansion of new constructions and reconstructions.

Changes in Lithuania's construction output (see Table 1) illustrate the fluctuations in the output of 
Table 1. Changes in Lithuania's GDP, construction and industry output

\begin{tabular}{|c|c|c|c|}
\hline Years & $\begin{array}{c}\text { Annual changes in GDP, } \\
\%\end{array}$ & Annual construction changes, \% & $\begin{array}{c}\text { Annual industry } \\
\text { changes, } \%\end{array}$ \\
\hline 1991 & & -27.4 & -4.8 \\
\hline 1992 & -34 & -22.6 & -28.6 \\
\hline 1993 & -30.4 & -36.6 & -34.4 \\
\hline 1994 & 1 & 3.5 & -38.1 \\
\hline 1995 & 3.3 & 0.4 & 5.3 \\
\hline 1996 & 4.7 & -11.6 & 3.0 \\
\hline 1997 & 7.3 & 9.4 & 8.2 \\
\hline 1998 & 5.1 & 20.5 & -11.2 \\
\hline 1999 & -4.1 & -16.4 & 2.2 \\
\hline 2000 & 4.0 & -17.8 & 16.0 \\
\hline 2001 & 6.5 & 7.5 & 3.1 \\
\hline 2002 & 6.7 & 13.1 & \\
\hline
\end{tabular}

construction industry in Lithuania, with sharp drops and rises of the values observed. Under these changing conditions, a question arises - how to improve the construction situation? One option could be modelling the Lithuanian construction industry to enable the creation of an efficient environment for the development of construction.

\section{Survey of Investigations in the Field of Conceptual and Quantitative Analysis of Construction}

The trends of construction development were investigated by researchers from various countries in a conceptual (textual, graphical (schemes, graphs, diagrams, drawings), etc. information) and quantitative forms. For example, according to R. C. Harvey $[1,2]$, past, present and future construction is closely connected with major economic indices of the state, such as total domestic product, state expenditures, consumer expenditures, fixed investment, average earnings, retail prices, disposable income, interest rate, etc. To prove this idea R. C. Harvey [1, 2] presents some conceptual material. A. Akintoye [3] (1998 analyzed the relationship between cost of construction in UK in 1974-1990 and 23 economic factors (i.e. rate of pound and unemployment, volume of construction, total domestic product, actual interest rate, income per capita, company's taxes, number of private contractors, etc.). The above analysis was made in textual, numerical and graphical forms, yielding diverse results. Researchers from Salford university [4] analyzed (in 1955-1994) and predicted (since 1994) the investment in UK construction, volume of construction, number of workers employed in this branch, as well as investigating the relationships among various factors. R. H. Barnard [5] and P. H. Hillebrandt [6] studied the relationship between the demand for construction products and the economic situation and social and economic policy of the state. G. Briscoe [7] analyzed the relationship between interest rate and state support in dwelling purchasing by the inhabitants, etc. and the investment in construction. R. C. Harvey [2] studied the effect of amalgamation of building firms on the increase of construction efficiency. P. H. Hillebrandt [6] described some ways of increasing the export of construction products.

The investigations of foreign economists and the practice of foreign countries show that relatively lower taxes in most cases give a country more of economic and social benefit. The economist K. Marsden [8] performed in mid-seventies an analysis of relationship between economic growth and taxes in twenty countries. Ten of the countries under investigation had high taxes, and the other ten - relatively low taxes. The countries of low taxes experienced rapid growth of employment, capital outlay and labour productivity not only in private, but also in public firms. Investments in low-tax countries increased on the average by $9 \%$ and, during the same period, in high-tax countries they dropped by $0,8 \%$. The investigations show that an increase of corporation income taxes by $1 \%$ causes a slow-down of investment rate by $2 \%$. Large extent investment in private sector is an important factor of economic growth because the acquired financial means serve for essential modernization of production and technology what usually has a positive effect on the development of economy. The economist of Dallas University J. Skali [8] has also performed an investigation of relationship between tax rates and economic growth in 103 countries. The investigations also indicated that countries with tax rate of up to $19,3 \%$ had an economic growth of $24 \%$ during the investigation period, and countries with tax rate of $43,2 \%$ had an economic growth not exceeding $0,4 \%$. 
Current state of housing and the trends of its development were analyzed from various perspectives by a number of foreign scientists. For instance, $P$. Balchin [9] studied economic, social and political problems related to dwelling acquisition. M. Ball [10] considered the problems of reducing state expenditures on dwelling, crediting, long-term loans and their various economic, social and political aspects. R. C. Harvey [1] analyzed the way the government can affect the construction market through finances, regulating documentation and contracts. In particular, he studied UK dwelling subsidies, funding and taxes and their effect on demand and offer. J. Hegedus [11] investigated housing strategy in Central and Eastern Europe while P. H. Hillebrandt [6] considered the ways of saving energy in operating buildings. J. Hills [12] summarised the cases when the government may intervene into construction market and the instruments of this intervention. He also dealt with some social problems related to housing. J. Sillince [13] studied some economic, social and political problems of housing. Conceptual study of these problems was also performed by R. Grover [14], J. Kursis [15], P. Malpass [16], I. S. Stepanov [17], C. Zimmermann [18] and others.

Presently, a great number of investigations [19] have been made all over the world to determine the level of state development depending on some quantitative and qualitative indices. These studies are primarily based on conceptual description being supplied by quantitative analysis. Quantitative expression of various factors in numbers, units of measure and their comparison did not present any difficulties. Major problems arose while comparing the economic development of various countries based on qualitative criteria. For example, some difficulties were encountered in numerical evaluation of the development of Eastern and Central European countries [19] when studying their quantitative indices, related to privatization, industry restructuring, price liberalization, banking reform, competition policy, etc.). In this research (as well as in similar ones), qualitative criteria are most often assessed conventionally in scores or per cent.

\section{Analysis of Lithuania's Transitional Construction}

\subsection{Clout of Construction on the Lithuanian Economy}

The construction industry is highly dependent on Lithuania's general national economic level. The volume of contracted construction work is directly related to the demand for buildings, which in turn is closely tied to the demand for other products and services. The more developed the various sectors of industry are and the more available the services are in a country, the higher the demand will be for different types of buildings. This means that investments made in various activities over the long run will be transformed into construction investments. And, the constructed buildings will be used for many different industrial and service purposes.

In Lithuania the construction output as part of the GDP accounted for $9.32 \%$ in $1992,5.1 \%$ in 1993 , $7.2 \%$ in $1994,7.1 \%$ in $1995,7.1 \%$ in $1996,7.5 \%$ in $1997,8.0 \%$ in $1998,6.9 \%$ in $1999,6.1 \%$ in 2000 and $6.1 \%$ in 2001 (see Table 2).

Table 2. Percentage of construction added value in GDP and construction employment in national employment

\begin{tabular}{|c|c|c|}
\hline Years & $\begin{array}{c}\text { Percentage of construction added value in } \\
\text { GDP and recent evolution (constant } \\
\text { prices) }\end{array}$ & $\begin{array}{c}\text { Percentage of construction employment } \\
\text { (construction firms) in national employment } \\
\text { and recent evolution }\end{array}$ \\
\hline 1970 & 9.9 & 9.1 \\
\hline 1975 & 10.72 & 8.8 \\
\hline 1980 & 9.31 & 7.7 \\
\hline 1985 & 8.21 & 7.8 \\
\hline 1990 & 10.11 & 9.6 \\
\hline 1991 & 6.21 & 7.8 \\
\hline 1992 & 9.32 & 9.1 \\
\hline 1993 & 5.1 & 7.1 \\
\hline 1994 & 7.2 & 6.6 \\
\hline 1995 & 7.1 & 7.0 \\
\hline 1996 & 7.1 & 7.2 \\
\hline 1997 & 7.5 & 7.1 \\
\hline 1998 & 8.0 & 7.1 \\
\hline 1999 & 6.9 & 6.6 \\
\hline 2000 & 6.1 & 6.1 \\
\hline 2001 & 6.1 & 6.2 \\
\hline
\end{tabular}

Source: Lithuania's Statistical Yearbook 
The independent Lithuanian years (1991-2000) were not favourable for the development of construction nor for the other industrial sectors. The 1991-2000 years have been a period of painful and complicated transition from a planned economy to a market economy. According to the Lithuanian Statistics Department, during the 1991-1998 period, the construction output defined by relative prices plunged nearly $50 \%$, while the total output from the construction materials industry shrank more than fivefold.

When the building sector of Lithuania was in a planned economy (until 1991) it was given much more attention; later, in the transition period, the situation has changed. This can be easily seen from Table 2 . In 1970-1990 construction added value in GDP fluctuated from 8.21 to 10.72 per cent, in the transition period (according to date for the years 1993-2001) this figure decreased to 5.1-8.0 per cent. $2001 \mathrm{~m}$. Although the construction added value in GDP has decreased considerably during the transition period in Lithuania, it remains higher as compared with developed countries (see Table 3). Due to characteristic features of the transition period (rapid political, economic, legal, infrastructural and other changes) from 1990 to 2000 Lithuania had the greatest changes in construction added value in GDP (198\%) compared to the developed countries of the world (Table 3 ). The construction added value in GDP in these countries during the same period changed by 127-147 per cent.

In the years of transition economy in Lithuania (since 1991) the percentage of construction employment in national employment has decreased considerably. In 1970-1991 this figure varied from 7.7 to 9.6 per cent; in the transition period, however, it decreased to 6.27.8 per cent (with the exception of 1992). This corresponds to the level of the EU countries under consideration. The variation of the percentage of construction employment in national employment in Lithuania during the time of reforms of transition period, however, was higher than in the EU countries (157\% and $121-135 \%$ respectively) (see Table 4$)$. It is also worth mentioning that in the EU countries the percentage of construction added value in GDP is

Table 3. Percentage of construction added value in GDP and recent evolution [20, 21, 22, 23, 24, 25, 26, 39-54]

\begin{tabular}{|c|c|c|c|c|c|c|}
\hline & Denmark & France & Germany & Lithuania & Sweden & UK \\
\hline 1990 & 4,7 & 6,2 & - & 10,1 & 5,0 & \\
\hline 1991 & 4,4 & 6,2 & 6,0 & 6,2 & 5,0 & 6,1 \\
\hline 1992 & 4,4 & 6,3 & 6,6 & 9,3 & 4,8 & 5,5 \\
\hline 1993 & 3,9 & 5,7 & 6,7 & 5,1 & 4,4 & 5,1 \\
\hline 1994 & 4,0 & 5,5 & 7,0 & 7,2 & 4,2 & 5,2 \\
\hline 1995 & 4,1 & 5,4 & 6,8 & 7,1 & 4,1 & 5,2 \\
\hline 1996 & 4,2 & 5,1 & 6,3 & 7,1 & 4,0 & 5,1 \\
\hline 1997 & 3,9 & 4,5 & 6,0 & 7,5 & 3,8 & 5,2 \\
\hline 1998 & 3,9 & 4,3 & 5,6 & 8,0 & 3,7 & 5,2 \\
\hline 1999 & 3,7 & 4,3 & 5,3 & 6,9 & 3,7 & 5,2 \\
\hline 2000 & 3,7 & 4,3 & 4,9 & 6.2 & - & \\
\hline \multicolumn{7}{|c|}{ The utmost variation in per cent } \\
\hline & 127 & 147 & 143 & 198 & 135 & 120 \\
\hline
\end{tabular}

Table 4. Percentage of construction employment in national employment and recent evolution [20, 21, 22, 23, 24, $25,26,39-54$

\begin{tabular}{|c|c|c|c|c|c|}
\hline & Denmark & Germany & Lithuania & Sweden & UK \\
\hline 1990 & 6,1 & - & 9.6 & 7,2 & \\
\hline 1991 & 5,8 & 7,3 & 7.8 & 7,3 & 7,8 \\
\hline 1992 & 5,5 & 7,7 & 9.1 & 6,6 & 7,1 \\
\hline 1993 & 5,0 & 8,1 & 7.1 & 6,1 & 6,8 \\
\hline 1994 & 5,0 & 8,5 & 6.6 & 5,7 & 6,8 \\
\hline 1995 & 5,4 & 8,6 & 7.0 & 5,8 & 6,7 \\
\hline 1996 & 5,6 & 8,4 & 7.2 & 5,7 & 6,6 \\
\hline 1997 & 5,7 & 8,1 & 7.1 & 5,5 & 6,3 \\
\hline 1998 & 5,8 & 7,7 & 7.1 & 5,5 & 6,4 \\
\hline 1999 & 5,9 & 7,4 & 6.6 & 5,5 & 6,4 \\
\hline 2000 & 6,0 & 7,1 & 6.1 & 5,4 & \\
\hline \multicolumn{6}{|c|}{ The utmost variation in per cent } \\
\hline & 122 & 121 & 157 & 135 & 124 \\
\hline
\end{tabular}


traditionally lower than the percentage of construction employment in national employment. This means that in order to create 1 per cent of GDP in the construction industry of these countries more than 1 per cent of the country's labor force is needed. The situation in Lithuania, which is making the transition to market economy, generally is opposite: traditionally less than 1 per cent of the country's labor force is used to create 1 per cent of GDP.

\subsection{Building Structure Stocks and Production}

As of January 1, 1997, building structure stocks represented $46.4 \%$ of the country's non-financial assets and were estimated at 27055 million Euros, or 2.83 times the GDP. In Lithuania this figure is average compared with developed countries of the world: Australia (2 \%), Canada (1.97\%), Denmark (1.96\%), France $(2.6 \%)$, Germany (4\%), Portugal (1.52\%), Sweden (1.61 \%) and UK (5.1\%). Public ownership accounted for $57.2 \%$ and private ownership $42.8 \%$ of the net stock of building structures in Lithuania (see Table 5).

Table 5. Estimation and ownership of the net stock of building structures in Lithuania in 1997 (as of January 1)

\begin{tabular}{|l|c|c|}
\cline { 2 - 3 } \multicolumn{1}{c|}{} & Amount & Parts in $\%$ \\
\hline Public & 8078.2 & 70.1 \\
\hline Private & 18977.1 & 29.9 \\
\hline Total & 27055.3 & $100.0 \%$ \\
\hline
\end{tabular}

Units : Euro millions

Source: Lithuania's Statistical Yearbook [16]
The production of residential houses represented 7$10 \%$ of the total, non-residential buildings $47-50 \%$ and civil engineering $42-44 \%$ in 1997-2000. Nonresidential buildings and civil engineering were the most important sub-segments of construction in 19972000 (see Table 6).

As can be seen from tables 6 and 7, the shares of residential houses, non-residential buildings and civil engineering in Lithuania differ from similar indices in the highly industrialized countries. The volume of residential construction in Lithuania, for instance, is too low and the volume of non-residential buildings and civil engineering is leading compared with industrialized countries. This can be explained by the fact that in a planned economy the state allocated much resources to the construction of residential buildings and in a market economy the amount of funds allocated for this purpose has been reduced considerably. The growth of investments of private citizens into construction of residential buildings does not fully offset the decrease in public investment. Although the share of investment coming from various organizations have increased, most of these funds are used for non-residential and civil engineering construction (Table 6 and 8). During the transition economy period in Lithuania, the reduced financial resources of private citizens and the state are allocated for construction projects to a lesser degree than those of various organizations (Table 8).

Table 6. Work carried out within the country by type of construction units (in percentages)

\begin{tabular}{|c|c|c|c|c|c|c|c|c|}
\hline & \multicolumn{2}{|c|}{ Total } & \multicolumn{2}{|c|}{ Public enterprises } & \multicolumn{2}{|c|}{$\begin{array}{c}\text { Joint-stock and private } \\
\text { companies }\end{array}$} & \multicolumn{2}{|c|}{$\begin{array}{c}\text { Individual (personal) } \\
\text { enterprises }\end{array}$} \\
\hline & $\begin{array}{l}1997 / \\
1998 \\
\end{array}$ & $\begin{array}{l}1999 / \\
2000 \\
\end{array}$ & $\begin{array}{l}1997 / \\
1998 \\
\end{array}$ & $\begin{array}{l}1999 / \\
2000 \\
\end{array}$ & $\begin{array}{l}1997 / \\
1998 \\
\end{array}$ & $\begin{array}{l}1999 / \\
2000 \\
\end{array}$ & $\begin{array}{l}1997 / \\
1998\end{array}$ & $\begin{array}{l}1999 / \\
2000\end{array}$ \\
\hline Total & $\begin{array}{l}100 / \\
100\end{array}$ & $\begin{array}{l}100 / \\
100\end{array}$ & $\begin{array}{l}100 / \\
100\end{array}$ & $\begin{array}{l}100 / \\
100\end{array}$ & $\begin{array}{l}100 / \\
100\end{array}$ & $\begin{array}{l}100 / \\
100\end{array}$ & $\begin{array}{l}100 / \\
100\end{array}$ & $\begin{array}{l}100 / \\
100\end{array}$ \\
\hline Residential houses & $7 / 7$ & $10 / 10$ & $1 /-$ & $-/ 1$ & $7 / 7$ & $10 / 10$ & $7 / 5$ & $13 / 12$ \\
\hline $\begin{array}{l}\text { Non-residential } \\
\text { buildings }\end{array}$ & $49 / 50$ & $47 / 47$ & $17 / 12$ & $10 / 14$ & $51 / 53$ & $48 / 48$ & $64 / 53$ & $56 / 52$ \\
\hline Civil engineering & $44 / 42$ & $44 / 43$ & $82 / 88$ & $90 / 85$ & $42 / 40$ & $42 / 42$ & $29 / 42$ & $31 / 36$ \\
\hline
\end{tabular}

Source: Lithuania's Statistical Yearbook [16]

Table 7. Shares of residential, non-residential, civil engineering [20, 21, 22, 23, 24, 25, 26, 39-54]

\begin{tabular}{|l|c|c|c|c|c|c|c|c|}
\hline & $\begin{array}{c}\text { Australia } \\
(2001)\end{array}$ & $\begin{array}{c}\text { Denmark } \\
(2000)\end{array}$ & $\begin{array}{c}\text { France } \\
(2000)\end{array}$ & $\begin{array}{c}\text { Germany } \\
(1999)\end{array}$ & $\begin{array}{c}\text { Lithuania } \\
(2000)\end{array}$ & $\begin{array}{c}\text { Portugal } \\
(1995)\end{array}$ & $\begin{array}{c}\text { Sweden } \\
(2000)\end{array}$ & UK \\
\hline \% residential & 39 & 36 & 45 & 57 & 10 & 45 & 34 & 41 \\
\hline \% non- residential & 26 & 35 & 32 & 27 & 47 & 23 & 44 & \multirow{2}{*}{559} \\
\hline \% civil engineering & 35 & 29 & 23 & 16 & 43 & $32 *$ & 22 & 22 \\
\hline
\end{tabular}


Table 8. Shares of households, firms, government [20, 21, 22, 23, 24, 25, 26, 39-54]

\begin{tabular}{|l|c|c|c|c|c|c|}
\hline & $\begin{array}{c}\text { Australia } \\
(2000)\end{array}$ & $\begin{array}{c}\text { France } \\
(2000)\end{array}$ & $\begin{array}{c}\text { Germany } \\
(2000)\end{array}$ & $\begin{array}{c}\text { Lithuania } \\
(1999)\end{array}$ & $\begin{array}{c}\text { Sweden } \\
(1999)\end{array}$ & $\begin{array}{c}\text { UK } \\
(1999)\end{array}$ \\
\hline \% households & 37 & $33^{*}$ & 25 & 8 & 14 & 23 \\
\hline \% firms & 43 & 39 & 47 & 86 & 61 & 55 \\
\hline \% government & 20 & 28 & 28 & 6 & 25 & 22 \\
\hline
\end{tabular}

\subsection{Improvement-Maintenance Activities}

The costs for Lithuanian energy resources have significantly increased over the last 13 years. These increases in energy resources have brought about, in turn, increased heating costs, accounting for a considerable part of a family's budget. Existing residential houses (especially large-panel housing) have deteriorated and have become obsolete. Deterioration, obsolescence and housing values have changed over time and depend on various factors, such as physical state, management, legal, architecture, aesthetic, function, comfort, maintenance, social, as well as defects in engineering services.

At present, some Lithuanian low income inhabitants (i.e. pensioners, the unemployed and large families) cannot afford to pay heating costs. The renovation of a building's heating system and insulation would reduce heating costs and save state social expenditures. In addition, the political party in power, which cannot solve this urgent problem in a rational way, will probably not win the upcoming election. The construction problem is not only a social problem, but a political one as well.

In 2002, improvement and maintenance activities represented $63.4 \%$ of the declared construction work (see Table 9). Percentages tended to increase over longer periods of time.
The volume of construction of new buildings, repair and maintenance of civil engineering in Lithuania differs from that in developed countries of the world (see Table 10). For example, the volume of new construction building is inadequately low (neither state nor private citizens have enough financial resources (Table 8)), and repair and maintenance of civil engineering is much more active than in developed countries of the world. During the period of planned economy civil engineering construction was rather active; recently, however, it failed to meet all the applicable requirements. Thanks to considerable investments made by the EU and the Lithuanian government the situation with regard to repair and maintenance for civil engineering has been improved (Table 10).

\section{Analysis of the Weak and Strong Points of the Lithuanian Construction Sector System}

By modelling and forecasting future perspectives and trends of construction industry, it is possible to get ready to respond to the changes of macro and microlevel variables (enterprise restructuring and structural change, sources of company finance, information system of construction, construction employers associations, education and training, types of contracts, the policy pursued by the government, legal and institutional infrastructure, physical infrastructure,

Table 9. Share of reconstruction, repair and restoration in declared Lithuanian construction works (in percent) (1996-1999)

\begin{tabular}{|l|c|c|c|c|c|c|c}
\hline & 1996 & 1997 & 1998 & 1999 & 2000 & 2001 & 2002 \\
\hline Reconstruction & 16 & 18 & 23 & 22.6 & 25.6 & 23.5 & 25.7 \\
\hline Repair and restoration & 45 & 43 & 38 & 38.6 & 35.4 & 35.4 & 32.7 \\
\hline Other work & 1 & 2 & 2 & 2 & 4.3 & 3.7 & 5 \\
\hline Total & 62 & 63 & 63 & 63.2 & 65.3 & 62.6 & 63,4 \\
\hline
\end{tabular}

Source: Lithuania's Statistical Yearbook [16]

Table 10. Parts of new construction and repair \& maintenance $[20,21,22,23,24,25,26,39-54]$

\begin{tabular}{|c|c|c|c|c|c|c|c|}
\hline & $\begin{array}{c}\text { Canada } \\
(1997)\end{array}$ & $\begin{array}{c}\text { Denmark } \\
(2000)\end{array}$ & $\begin{array}{l}\text { France } \\
(2000)\end{array}$ & $\begin{array}{c}\text { Germany } \\
(1999)\end{array}$ & $\begin{array}{c}\text { Lithuania } \\
\text { (1999) }\end{array}$ & \begin{tabular}{|c|c|} 
Sweden \\
$(2000)$
\end{tabular} & UK \\
\hline$\%$ new construction building & 41 & 33 & 40 & 51 & 20 & 25 & 48 \\
\hline \% repair \& maintenance building & 21 & 38 & 37 & 34 & 27 & 53 & $25^{*}$ \\
\hline$\%$ new construction civil engineering & 36 & 17 & 15 & 11 & 17 & 17 & 8 \\
\hline \% repair \& maintenance civil engineering & 2 & 12 & 8 & 4 & 36 & 5 & $19^{*}$ \\
\hline
\end{tabular}

* figure for building includes only residential R\&M, and the figure for civil engineering includes all non-residential R\&M (including commercial, etc.). 
financial sector, interest rate, inflation, innovations, etc.) in Lithuania.

The model of efficient construction industry suggested by authors $[26,27,28-30,31-33]$ is based on presumption that the efficiency of construction industry depends on many micro and micro-level variables. The presence of specific macro and microlevel variable factors right away imposes objective limitations for efficient activities of construction industry. The construction industry, in presence of these objective limitations, tries to perform its functions in their bounds with utmost efficiency. For instance, organizations, being in dependency upon certain macro and micro-level environment, would do their best to look for activities in such fields of construction industry as designing, production of building materials, tools and mechanisms, construction of dwelling houses, thermal refurbishment of buildings, supply, etc., and in geographic locations including the capital, various towns and districts of the country, rural districts, etc. as well as working and with such interested parties the goals of which would find maximum satisfaction. Advanced organizations, basing themselves on this assertion, are trying to create for themselves rational environmental and operating conditions in order to achieve the best satisfaction of customers' needs, to win better reputation and to earn more profit. Therefore, basing oneself on main development trends of construction industry in advanced industrial countries, it is possible to issue recommendations on the increase of efficiency of transition construction industry in Lithuania. When rational variable micro and micro-level factors determines for Lithuania have been realized, they should create better and more favourable conditions for efficient realization of construction industry's projects would be created.

The research aim $[26,27,28-30,31-33]$ was to produce an analytical model of the rational construction industry in Lithuania by undertaking a complex analysis of micro and macro environment factors affecting it and to give recommendations on the increase of its competitive ability. The research was performed by studying the expertise of advanced industrial economies and by adapting it for Lithuania, taking into consideration specific history, development level, needs and traditions. Simulation was undertaken to provide insight into creating an effective environment for the construction industry by choosing rational micro and macro factors.

The organizations of construction industry cannot correct or alter the micro and micro-level variables, but they can go into the essence of their effect and take them into consideration when realizing various projects. Organizations, knowing the micro and microlevel factors affecting the projects being realized, can organize their present and future activities more successfully.

During an analysis the following weak points the Lithuanian construction sector were established:

- Many ministries or their sub-ordinated institutions, counties, and municipalities regulate construction activities. Laws on Environmental Protection, Roads, Communications and other sectors supplement the laws on the Planning of Territories and Construction. Activities of such ministries or their sub-ordinated institutions are not always co-ordinated, and some functions are, in fact, duplicated.

- $\quad$ Ministries, counties, and municipalities regulating construction activities are often striving to achieve different objectives and perceive the market economy in different ways - from strict state control to unrestricted market operation.

- No legal environment exists to facilitate and stimulate innovative development.

- The supply of efficient energy and ecological construction services and products is not promoted.

- The preparation of new documents regulating construction activities is considerably weak due to insufficient financial resources.

- $\quad$ Since the Lithuanian construction market is fragmentised, and residents have only comparatively restricted purchasing power, the construction potential is not totally exploited.

- The construction potential available cannot be effectively exploited because of the economic recession in Lithuania and the neighbouring countries.

- The construction sector's companies are too small to compete alone in the international market. The Lithuanian construction companies do not have enough experience to form timely temporary alliances and combine their resources and experience for the implementation of certain export projects.

- The Lithuanian Government is weakly participating in supporting attempts by enterprises to penetrate into foreign markets.

- $\quad$ Ongoing studies are conducted inefficiently and ineffectively.

- The Lithuanian construction information system is in its initial phase of creation.

- Many Lithuanian construction organisations, especially small- and medium-sized enterprises, are not taking advantage of the opportunities 
offered by information and Internet technologies at all or only in a minor manner.

- Financing of housing programs requires a substantial portion of state budget funds, which could be used in other fields of activities.

- Public utilities funding to needy people is a major expenditure and problem in the state budget.

- Lithuania is far from the European average in apartments per 1000 residents. State funding for housing acquisition has continued to fall off since 1998.

- $\quad$ No detailed strategy and planning documents are available in connection with the housing acquisition policy, nor details on housing policy objectives.

- The problem of social housing is not taken into consideration. 10-40 percent of all the housing funds allotted in Western countries are earmarked for social housing; however, Lithuania's social housing funds amount to less than 3 percent of the state budget.

- Lithuania has inherited an irrational building materials and products manufacturing industry, requiring huge investments for modernisation.

- A lack of funds is reducing the possibilities of competing with foreign companies. Very few investments were allotted for the implementation of new technologies over the last decade.

- Relations between employers and employees are not at their best.

- Lithuanian construction associations (Lithuanian Contractors' Association, Lithuanian Union of Civil Engineers, Association of Construction Industry, etc.) are not representing the interests of organisations very well abroad, nor solving the problems of occupational training and improvement of qualification.

- Inefficient traditional construction organisational models continue to prevail.

- The level of investment allotted for the development of science and technologies is too low compared with other countries.

- Cooperation between construction enterprises and institutions of science and technologies and universities is at a very low level.

- Stagnant cash flow and low profitability characterise the construction sector.

- A systematic financial reform of mechanisms is not being performed (weak financial services sector; poor financial resources selectivity).

- Interest rates are too high.

- Land ownership is still an unsolved problem.

The Lithuanian construction sector's strong points are as follows:
- The Seimas has adopted a new Law on Construction, concordant with EU requirements. By amending the Law on Construction, the project agreement procedure valid for decades has been revamped. Up until now, the draft agreement procedure usually called for several months to be concluded, resulting therefore in price hikes for projects. Today, the time to sign a construction project agreement and issue a building permit has been reduced to 30 or 35 days.

- Government controlled construction companies have been privatised and restructured.

- The housing sector has been privatised.

- Construction sector basics are good, as well as strong traditions.

- The preparatory system for construction specialists has been developed; with a qualified potential for scientists.

- Present conditions in housing credits and state guarantees are better in Lithuania than in many other Central and Eastern European countries.

- After a reorganisation of real estate land surveying and registering, a mortagage based infrastructure has been created; therefore, housing mortgage credits have commercially increased.

- The financing of housing programs by the state budget and international support is reviving the Lithuanian financial market.

- A favourable macro-economic environment exists (economic growth, low inflation, etc.).

After the analysis just made of the weak and strong points of the Lithuanian construction sector system and in order to enhance its competitiveness, we suggest proceeding with the following main actions and initiatives:

- Review the normative documents and legal acts regulating the construction of ministries, counties, and municipalities and constitute a joint system of the state's technical and special requirements in order to eliminate duplication, as well as unimportant or contradictory documents.

- Ensure Lithuanian state institutions and the construction organisation fight more actively for quotes allowing construction activities in foreign countries.

- $\quad$ Support the Lithuanian construction exporters by both financial and non-financial means.

- Create an Internet system of the Lithuanian construction sector in its entirety.

- Create a national system of normative documents and legal acts regulating the construction business in compliance with EC requirements.

- Create a legal environment facilitating the 
development and promotion of innovation.

- Promote ecological and energy-efficient construction products and services.

- Participate actively in EC-financed infrastructure development projects.

- Improve normative documents and legal acts regulating the construction business and strive for their conformity with the best international practices.

- Promote construction under completion and renovation of old housing.

- Co-ordinate educational programmes and ongoing higher education studies at the national level in Lithuania. Improve their quality and effectiveness.

- Create a promotional system inspiring an interest by both companies and their employees for improved qualifications.

- Promote and support the implementation of upto-date achievements in information and Internet technologies under construction. Stimulate Lithuanian construction companies to benefit more effectively from the opportunities offered by information and Internet technologies at the following three levels in the construction sector (country, organisations, and projects).

- Formalise the normative documents and legal acts regulating the construction business in order to concur with European Union requirements.

- Initiate the construction of low-income/social housing.

- Implement integrated design technologies.

- Reform work relations in the construction business. Issue a guide offering advice to construction workers on how to carry out on-thejob relations more effectively.

- Implement up-to-date achievements in facilities and property management.

\section{Conclusion}

Above research illustrate the fluctuations in the output of construction industry in Lithuania, with sharp drops and rises of the values observed. Under these changing conditions, a question arises - how to improve the construction situation? One option could be modelling the Lithuanian construction industry to enable the creation of an efficient environment for the development of construction. In modelling and forecasting future perspectives and the main development trends of the Lithuanian construction industry, it is possible to be prepared for effective changes in environment. The analysis of construction industry in developed countries and Lithuania can allow identify areas where the situation in Lithuania is comparable, partly comparable with or quite different from the level attained by the developed countries. The data of above analysis can be used in identifying construction industry development trends in developed countries as well as providing some recommendations for Lithuania. After the analysis of the weak and strong points of the Lithuanian construction sector system and in order to enhance its competitiveness, some main actions and initiatives were proposed.

\section{References}

1. Harvey, R. C.; Ashworth, A. The construction industry of Great Britain. Butterworths, London, 1997, p. 321.

2. Harvey, R. C.; Ashworth, A. The construction industry of Great Britain. Butterworths, London, 1993, p. 292.

3. Akintoye, A.; Bowen, P.; Hardcastle, C. Macro-economic leading indicators of construction contract prices. Construction management and economics. London, Routledge, 16, 1998, p. 159-175.

4. Construction forecasting: A new approach to construction industry forecasting. The Royal Institution of Chartered Surveyors. London, 1996, p. 82.

5. Barnard, R. H. Survival or Success: Developing an appropriate response to a fluctuating demand for the building firm. Chartered Institute of Building, Occasional Paper No. 25, 1979.

6. Hillebrandt, P. H. Analysis of the British construction industry. Macmillan Press, London, 1988, p. 338.

7. Briscoe, G. The economics of the construction industry. Mitchell, London, 1988.

8. Industry economics (Экономика промышленного производства), 1992, No 2, с. 132-138 (in Russian).

9. Balchin, P. Housing policy. Routledge, New York, 1995, p. 312 .

10. Ball, M.; Harboe, M.; Martens, M. Housing and social change in Europe and the USA. Routledge, London, 1990, p. 224.

11. Hegedus, J.; Mayo, S. K.; Tosics, I. Transition period's living construction in CEE countries (Rytų ir Centrinès Europos šaliu pereinamojo laikotarpio būsto sektorius). Vilnius, 1997, p. 46 (in Lithuanian).

12. Hills, J. Unravelling housing finance: subsidies, benefits and taxation. Oxford University Press, Oxford, 1991, p. 338.

13. Sillince, J. Housing policies in Eastern Europe and the Soviet Union. Routledge, London, 1990, p. 488.

14. Grover, R. The development of a European housebuilding industry. Transactions of the European Symposium on Management, Quality and Economics in Housing and other Building Sectors held in Lisbon, 30 September - 4 October 1991. E\&FN Spon, London, 1991, p. 1688-1709. 
15. Kursis, J. Paradigm Shift in the Management of Public Housing in Sweden. International Conference on Facilities Management in Central and Eastern Europe and Commonwealth of Independent States. Vilnius, Lithuania May 14-15. Edited by E. Zavadskas, B. Sloan, A. Kaklauskas

16. Malpass, P.; Munie, A. Housing policy and practice. Macmillan Press, London, 1994, p. 360.

17. Stepanov, I. S. Construction economics (Экономика строительства). Jurait, 1997, p. 426 (in Russian).

18. Zimmermann, C. Assisted home-ownership in France. Proceedings of the XXV IAHS World Housing Congress. Lisbon, Portugal 29 June-3 July 1998. Edited by V. Abrantes. Porto, 1998, p.714.

19. Transition reports 1997-2000. European Bank for Reconstruction and Development, London, 1997-2000.

20. Carassus, J. A Meso-economic Analysis of the Construction Sector. Joint meeting of CIB W55/W65 and TG23/TG31/TG35. September 13-15, 2000. Reading.

21. Construction Sector System: A New Framework for the 21st Century. A Comparative International Study. Editor: Jean Carassus, 2002, p. 206.

22. Statistics Canada (2001) Canada Year Book.

23. Statistics Canada (1990 to 2000) Labour Force Survey.

24. Lopes, J.; Bezelga, A. A Mesoeconomic Analysis of the Construction Industry, Proceedings of the Joint Meeting of CIB Working Commissions W55 and W65 and Task Groups TG 23, TG 31 and TG 35, The University of Reading, UK, 2000, September 13-15.

25. de Valence, G. Trends in Procurement and Implications for Innovation and Competitiveness of Australian Building and Construction, CIB W65 World Building Congress, Wellington N.Z., CIB Publication, 2001.

26. Zavadskas, E.; Vitkauskas, A.; Kaklauskas, A. Selection of Efficient Standards for Building and Juridical Documents Regulating the Construction Process in the Former Soviet Countries / Institute of Technological and Economic Development (ITED). Series of Publications, Volume 3, Business Management. Vilnius: Technika, 1994, p. 140-145.

27. Kaklauskas, A. Total Life Analysis, Modelling and Forecasting of Construction in Lithuania. Research output. EC Phare-ACE Programme 1996. Contract Number: P96-6708-F, p. 56.

28. Zavadskas, E. K.; Sloan, B.; Kaklauskas A. Total life analysis, modelling and forecasting of the construction industry in Lithuania. In: Proceedings of the XXV IAHS World Housing Congress. Lisbon, Portugal 29 June - 3 July 1998. Edited by V.Abrantes. Porto, 1998, p. 69-78.

29. Zavadskas, E. K.; Jonaitis, V.; Kaklauskas, A.; Bainaitis, A. Total life analysis, modelling and forecasting of housing industry in Lithuania. In: Regional Workshop Housing and Environment. Viena International Center, 22-23 Nov. 1999 / United Nations
Center for Human Settlements (Habitat); compiled and edited by Baris Der-Petrossian.-Vienna, 2000, p. 360-372.

30. Zavadskas, E.; Kaklauskas, A. Modelling and forecasting of construction industry in Lithuania. In: $5^{\text {th }}$ International Conference "Integrating technology \& human decisions: global bridges into the $21^{\text {st }}$ century". Vol 2. Edited by D. K. Despotis and C. Zopounidis. New Technologies Publications, Athens, 1999, p. 2051-2053.

31. Zavadskas, E.; Rutkauskas, A. V.; Kaklauskas, A. Lietuvos racionalios statybos sakos modelio kurimas (Development of Rational Construction Industry Model). Statyba (Civil Engineering), Vol V, No 2, Vilnius: Technika, 1999, p. 123-134.

32. Zavadskas, E.; Kaklauskas, A.; Banaitis, A.; Jonaitis, V. Creation of Rational Enterpreneurship Conditions in Construction Industry of Lithuania. Statyba (Civil Engineering), Vol IV, No 1. Vilnius: Technika, 1998, p. 78-85.

33. Zavadskas, E.K.; Kaklauskas, A.; Banaitis, A. Analysis, modeling and forecasting of housing credit access. Property Management, 1999, 3(2), p. 101-118.

34. Investment in Tangible Fixed Assets and Construction (1991-2003). Vilnius, Department of Statistics under the authority of the Government of the Republic of Lithuania, 1992-2003.

35. Statistical Yearbooks of Lithuania (1990-2003). Vilnius, Department of Statistics under the authority of the Government of the Republic of Lithuania, 2001-2003.

36. Services 1999. Statistics Lithuania. Vilnius 2000. 44 p.

37. Ginevičius, R.; Andruskevicius, A. Planning of real estate guarantee service costs. Property Management, 2001, 5 (1), p. 33-35.

38. Zavadskas, E. K.; Kaklauskas, A.; Kvederyte, N. Multivariant design and multiple criteria analysis of a building's life cycle. Informatica, 2001, 12(1), p. 169188.

\section{Internet}

39. www.bundesbank.de

40. www.diw-berlin.de

41. www.encarta.msn.com

42. www.ifo.de

43. www.destatis.de

44. www.dst.dk

45. www.forum.europa.eu

46. www.abf.se

47. www.av.se

48. www.byggentreprenorerna.se

49. www.sabo.se

50. www.inv.se

51. www.skolverket.se

53. www.svefast.se

54. www.zdb.de
52. www.scb.se

55. www.bundesarchitektenkammer.de (May 2001)
(April 2001)

(April 2001)

(May 2001)

(March 2001)

(April 2001)

(June 2001)

(November 2001)

(June 2001)

(April 2001)

(May 2001)

(November 2001)

(May 2001)

(June 2001)

(April 2001)

(June 2001)

(April 2001) 